\title{
Projected Thermodynamic Efficiencies of Fusion Power Plants
}

by

M. A. McKinnon

September 1976

Prepared for the Energy Research and Development Administration under Contract E(45-1)-1830 
NOTICE

This report was prepared as an account of work sponsored by the United States Government. Neither the United States nor the Energy Research and Development Administration, nor any of their employees, nor any of their contractors, subcontractors, or their employees, makes any warranty, express or implied, or assumes any legal liability or responsibility for the accuracy, completeness or usefulness of any imformation, apparatus, product or process. disclosed, or represents that its use would not infringe privately owned rights.

\author{
PACIFIC NORTHWEST LABORATORY \\ operated by \\ BATTELLE \\ for the \\ ENERGY RESEARCH AND DEVELOPMENT ADMINISTRATION \\ Under Contract E(45-1)-1830
}

\author{
Printed in the United States of America \\ Available from \\ National Technical Information Service \\ U.S. Department of Commerce \\ 5285 Port Royal Road \\ Springfieid, Virginia 22151 \\ Price: Printed Copy \$5.00; Microfiche $\$ 2.25$
}


BNWL-2017

UC -20

PROJECTED THERMODYNAMIC EFFICIENCIES

OF FUSION POWER PLAINTS

by

M. A. McKinnon

September 1976

Battelle

Pacific Northwest Laboratories

Richland, Washington 99352 
Fusion reactor technology has developed far enough to expect laboratory demonstration of practical levels of fusion employing the D-T reaction to occur in the early 1980s. Following that demonstration, and depending upon the national priorities for energy from D-T fusion, construction and operation of experimental reactors and demonstration power reactors could occur before the end of this century. Operation of the first commercial power plants could then follow, starting about 2010 .

Development and adoption of a new power system eventually will require a description of the environmental effects in an environmental statement providing a comparison to the effects of competitive systems. In anticipation of that statement, an environmental analysis (BNWL-2010) has been prepared for the ERDA Division of Magnetic Fusion Energy. That analysis estimates the environmental effects of constructing and operating $D-T$ fusion reactors as an economically competitive source of electricity in the 21 st century.

The analysis has four primary purposes:

1. To describe the general nature of the environmental effects,

2. To determine current ability to estimate the effects,

3. To determine methods for reducing the effects, and

4. To determine research necessary for increasing capability to define and reduce the effects.

Timely identification of needed research and methods for reducing effects will permit the performance of that research and the revision of conceptual fusion power plant designs before preparation of the program environmental statement. This would improve the quality of the environmental statements and could reduce the estimated adverse environmental effects due to fusion power plants.

The environmental analysis (BNWL-2010) concludes that the following assumed characteristics are the best set for the first operating fusion power plants:

- The D-T fusion reaction

- Large quantities of activation products

- Kilogram quantities of tritium in the plant systems

- Massive reactor structures

- Large lithium inventories

- Large inventories of liquid metals and salts
- Standard electricity generation

- Standard radioactive waste systems

- Large magnetic fields

- A self-contained fuel cycle

- Rural siting

Using these characteristics a reference reactor was analyzed to determine the environmental effects by using available concepts of plant subsystems designs that control interactions with the environment or by assumption that best current technology would be used in subsystems design. Because this analysis does not take into account advances in both fusion and waste control technology during the next thirty years, the estimated effects probably are significantly higher than the actual effects will be for the first fusion power plants. The estimated environmental effects should be interpreted only as being the probable upper limit for the actual effects. 
Preparation of the fusion power plant environmental analysis required development and use of specially developed data and analysis methods not used in the preparation of current environmental statements for fossil and fission power plants. These data and analysis requirements are documented in a series of reference topical reports to make this information publicly available and to assure understanding of the basis for the conclusions made in the environmental analysis.

These reference topical reports sumarize the state-of-the-art as applicable to preparation of environmental statements for fusion power plants. They present the data and analytical techniques used in the environmental analysis to estimate the interactions with the environment and the resultant environmental effects. This information then was analyzed for adequacy and the need was determined for additional research to assure satisfactory ability to prepare environmental statements for the fusion development program and experimental facilities in the early 1980s. Estimated environmental effects are presented in these reference documents only as necessary to illustrate use of the data and analytical techniques.

This report is one of those reference documents for the environmental analysis. The other documents in this series contain more details of the power plant concepts and the probable environmental effects of fusion power plants with the assumed characteristics listed above. These documents are available through the National Technical Information Service:

An Environmental Analysis of Fusion Power to Determine Related R\&D Needs, BNWL-2010

Review of Fusion Research Program: Historical Summary and Program Projections, BNWL-2011

Fuel Procurement for First Generation Fusion Power Plants, BNWL-2012

Current Fusion Power Plant Design Concepts, BNWL-2013

Reference Commerical Fusion Power Plants, BNWL-2014

Siting Commercial Fusion Power Plants, BNWL-2015

Materials Availability for Fusion Power Plant Construction, BNWL-2016

Projected Thermodynamic Efficiencies of Fusion Power Plants, BNWL-2017

Tritium Source Terms for Fusion Power Plants, BNWL-2018

Management of Nontritium Radioactive Wastes from Fusion Power Plants, BNWL-2019

Methodology for Estimating Radiation Doses Due to Tritium and Radiocarbon Releases, BNWL-2020

Magnetic Field Considerations in Fusion Power Plant Environs, BNWL-2021

Biological Effects of Tritium Releases from Fusion Power Plants, BNWL-2022

Biological Effects of Activation Products and Other Chemicals Released from Fusion Power Plants, BNWL-2023

Safety Review of Conceptual Fusion Power Plants, BNWL-2024

An Investigation of the Transportation Requirements of Fusion Power Plants, BNWL-2025

Considerations of the Social Impact of Fusion Power, BNWL-2026

Environmental Impacts of Nonfusion Power Systems, BNWL-2027

Environmental Cost/Benefit Analys is for Fusion Power Plants, BNWL-2028

Biomagnetic Effects: A Consideration in Fusion Reactor Development, BNWL-1973

An Analysis of Tritium Releases to the Atmosphere by a CTR, BNWL-1938 


\section{CONTENTS}






\section{SUMMARY}

Estimated thermal efficiencies of proposed fusion power plant concepts are compared in this report to the efficiencies of nonfusion power plants. Present trends in electrical power generation are also discussed. The fusion reactor system designs will have about the same thermal efficiencies as present day power plants using steam if these designs require the collection of thermal energy at the blanket and the transfer of that energy to a heat exchanger or boiler using the current technology. Ample ability to estimate the thermal efficiency of fusion power plants currently is available. The thermodynamics of power conversion systems are well enough known that it is possible to estimate the thermal efficiency of any system for which the operating temperatures are known.

Two general methods should be pursued for increasing the thermal efficiencies of fusion power plants and thereby reducing the amount of waste heat. Methods should be developed for increasing the temperatures of the reactor coolants since the maximum attainable thermal efficiency of systems using coolants can be increased only by increasing the coolant temperatures. Second, advanced power recovery systems such as potassium topping turbines, MHn, and direct conversion should be developed since such systems avoid the limits on steam systems due to excessive operating pressures at high temperatures. Direct conversion is particularly attractive because it avoids the theoretical Carnot limit on thermal efficiency when heat is converted to electrical energy.

\section{RESEARCH REQUIREMENTS}

Energy conversion technology is well enough defined that no additional research on thermal conversion is needed to assure adequate preparation of environmental statements on the thermal effects of experimental or commercial fusion reactors. If thermal conversion systems are improved for fusion reactors, the information needed for defining the thermal efficiencies will be available with the system designs. 
BACKGROUND

The rapid depletion of our natural resources has focused additional attention on fusion power plant as a future energy source. Over the last 25 years, controlled thermonuclear research has emphasized the containment of fusion plasma to demonstrate the scientific feasibility of obtaining more energy from fusion reactions than is supplied to the plasma. Recent successes in plasma containment have caused scientists to look beyond plasma confinement problems and identify fusion reactor engineering problems which need solutions before useful power can be produced. The ultimate success of fusion reactors as a contributor to the U.S. power ecnnomy will depend on their performance in comparison to competing systems. This report compares the thermal efficiencies of current conceptual fusion reactors to the competing power systems to determine if there are any significant differences and to determine if additional research is needed to assure adequate estimates of fusion reactor thermal efficiencies.

Data from fusion power plant concepts being developed at various Energy Research and Development (ERDA) laboratories are used in this report. The concepts and their originators are:

- Tokamak

University of Wisconsin (UWMAK)

Brookhaven National Laboratory (BNL)

Princeton Plasma Physics Laboratory (PPPL)

Oak Ridge National Laboratory (ORNL)

- Theta Pinch Los Almos Scientific Laboratory (LASL)

- Mirror Lawrence Livermore Laboratory (LLL)

- Blascon ORNL

- Wetted Wall LASL

- Suppressed

Ablation 


\section{ENERGY CONVERSION}

The energy released in a fusion reaction comes from a conversion of mass to energy that is carried off as the kinetic energy of the reaction product particles. The collection and conversion of this energy is the function of the energy conversion device of the fusion power plant. Both charged particles (atomic nuclei) and uncharged particles (neutrons) can be produced in fusion reactions. The proportion of charged to uncharged particles and the amount of energy associated with each particle depends on the fuel cycle used. $(1,2)$ The energy of the neutrons is converted to heat as the neutrons collide with the reactor blanket. The heat can be converted to electricity by a thermal power plant. The energy associated with the charged particles can by collected as heat by allowing the particles to collide with the reactor blanket. Electric and magnetic fields could direct the motion of the charged particles while extracting energy from them. This would be a direct conversion of the energy to electricity.

The only currently proposed fusion power plant concept in which the energy of the charged particle is converted directly to electricity is the Mirror concept of Lawrence Livermore Laboratory (LLL). Charged particle energy conversion efficiencies of 85 percent for a 22-stage electrostatic collector were obtained in a laboratory setting. However, the economics of such a device would limit the electrostatic collector to one or two stages with efficiencies of 50 to 60 percent. (3) The energy required to run the reactor would further limit the overall efficiency of the concept to about 27 percent.

In other proposed fusion reactor concepts the energy of the charged particles is converted to heat and collected by the blanket. The conversion of the thermal energy thus generated to electricity requires a heat engine operating in a thermodynamic cycle. The energy not extracted as electricity by the direct conversion process or the heat engine is rejected as waste heat to the environment. The efficiency of a conversion 
system relates the energy converted, $Q_{e}$ (electrical), to the energy rejected, $Q_{r}$, by the following relationship; $Q_{r}=Q_{e}[(1-n) / n]$ where $n$ is the thermal efficiency. The thermal efficiency of a heat engine is limited by the second law of thermodynamics to be less than or equal to the Carnot efficiency

$$
{ }^{n} \text { Carnot }=\frac{T_{\text {high }}-T_{\text {low }}}{T_{\text {high }}}
$$

where the temperatures used are absolute temperatures. The maximum temperature is normally limited by containment methods. The low temperature is limited to the temperature of the environment.

Containment of high temperatures is limited by the properties and availability of materials. Boom et al., reports that typical stress levels of 10,000 to $20,000 \mathrm{lb} / \mathrm{in}^{2}{ }^{2} 1$ imit the useful operating temperatures to less than $1202^{\circ} \mathrm{F}\left(650^{\circ} \mathrm{C}\right)$ for 316 stainless steel, $1472^{\circ} \mathrm{F}\left(800^{\circ} \mathrm{C}\right)$ for vanadium and its alloys, $1832^{\circ} \mathrm{F}\left(1000^{\circ} \mathrm{C}\right)$ for niobium and its alloys, and $2192^{\circ} \mathrm{F}\left(1200^{\circ} \mathrm{C}\right)$ for molybdenum and its alloys. ${ }^{(4)}$ As these temperatures are approached the incidence of failure by creep, rupture, and fatigue are expected to rapidly increase. The materials with the best hightemperature strength cost more and are more difficult to fabricate than common materials.

\section{PROJECTED EFFICIENCIES OF FUSION POWER PLANTS}

Table 1 reviews the estimated design efficiencies of the proposed fusion reactor concepts. Even though the temperature of the reaction is of the order of millions of degrees, the high temperature strength of materials limits the temperature within the power conversion systems to $1832^{\circ} \mathrm{F}$ $\left(1000^{\circ} \mathrm{C}\right)$ or less. 
TABLE 1. Projected Efficiencies of Fusion Power Plants

Magnetic Power Plant

\begin{tabular}{|c|c|c|c|c|c|c|c|}
\hline Parameters & UWMAK-I & BNL Bianket & UWMAK-II & PPPL & $\underline{\mathrm{ORNL}}$ & $\Theta$ PINCH & MIRROR \\
\hline $\begin{array}{l}\text { Net Plant } \\
\text { Efficiency }\end{array}$ & 33 & 32 & 36 & 38 & 52 & 34 & 27 \\
\hline $\begin{array}{l}\text { Gross Thermal } \\
\text { Efficiency }\end{array}$ & 36 & 34 & - & 45 & 56 & 40 & $\begin{array}{l}45 / \\
70^{\star}\end{array}$ \\
\hline $\begin{array}{l}\text { Maximum Working } \\
\text { Fluid Temperature } \\
\left({ }^{\circ} \mathrm{C}\right)\end{array}$ & 489 & 727 & 650 & 638 & 1052 & 540 & 627 \\
\hline $\begin{array}{l}\text { Working } \\
\text { Fluids }\end{array}$ & $\begin{array}{l}\mathrm{Li} / \mathrm{Na} / \\
\text { Steam }\end{array}$ & He/Steam & He/Steam & $\begin{array}{l}\mathrm{Li} / \mathrm{K} / \\
\text { Steam }\end{array}$ & $\begin{array}{l}\mathrm{Li} / \mathrm{Na} / \\
\text { Steam }\end{array}$ & $\begin{array}{l}\mathrm{Li} / \mathrm{Na} / \\
\text { Steam }\end{array}$ & $\begin{array}{l}\mathrm{Li} / \mathrm{Na} / \\
\text { Steam }\end{array}$ \\
\hline
\end{tabular}

Laser Power Plant

Parameters

Net Plant

Efficiency

Gross Thermal

Efficiency

Maximum Working

Fluid Temperature

$\left({ }^{\circ} \mathrm{C}\right)$

Working

Fluids

$\mathrm{Li} / \mathrm{Na} / \mathrm{He} / \mathrm{Steam}$
Steam

(a)ASCON

WET WALL BLASCON SUPPRESSED ABLATION

27

36

40

40

44

*Direct conversion of charged particles.

In this table the net plant efficiency represents that portion of the energy generated in the reactor that is available as input to the electrical power grid. The gross efficiency represents the thermal efficiency of the energy conversion system. The difference between the two efficiencies is the amount of power required to heat and inject fuel into the reaction zone and to furnish power to auxiliary systems. 
Most of the fusion energy concepts operate in a pulsed manner. The cycle associated with their operation can be of the order of a tenth of a second to over an hour depending on the device. The designs have assumed that where needed, energy storage devices and thermal accumulators can be designed to smooth out the cyclic nature of the power output. The possible loss of efficiency due to the devices needed to smooth out the temperature and power transients has not been considered and research may be needed in design and development of economic thermal damping devices to assure availability of a satisfactory system for operation. Also, the stresses caused by the inherent thermal and pressure cycling of fusion reactor devices may require that their operating temperatures be limited to values less than for fission or nonnuclear power plants. This could also cause a decrease in their thermal efficiency. Although research may be needed to determine the best designs for the energy storage and heat transfer systems, that research is not needed to assure satisfactory estimation of thermal efficiencies.

\section{PRESENT AND PROJECTED EFFICIENCIES OF NONFUSION POWER PLANTS}

The present day and projected thermal efficiencies of other types of power plants are shown in Table 2. The table was compiled from data in several reports. $(2,4-14)$ Detailed descriptions of these systems are presented in another document in this series. (15)

Steam trubines presently constitute about 78 percent of the electricty generating capacity in the U.S. with average heat input to electric output conversion efficiencies of 33 percent. Maximum efficiencies are as high as 45 percent. With present materials, more efficient power plants can be built, but the costs are prohibitive. To increase the maximum operating temperature, the materials that must be used are an order of magnitude more expensive to obtain and much more costly to fabricate. A point is reached where the plant's increased efficiency cannot compensate for the increased cost of the improved plant. Factors which have a bearing on the efficiency of thermal power plants are the 
TABLE 2. Efficiencies in Power Generation

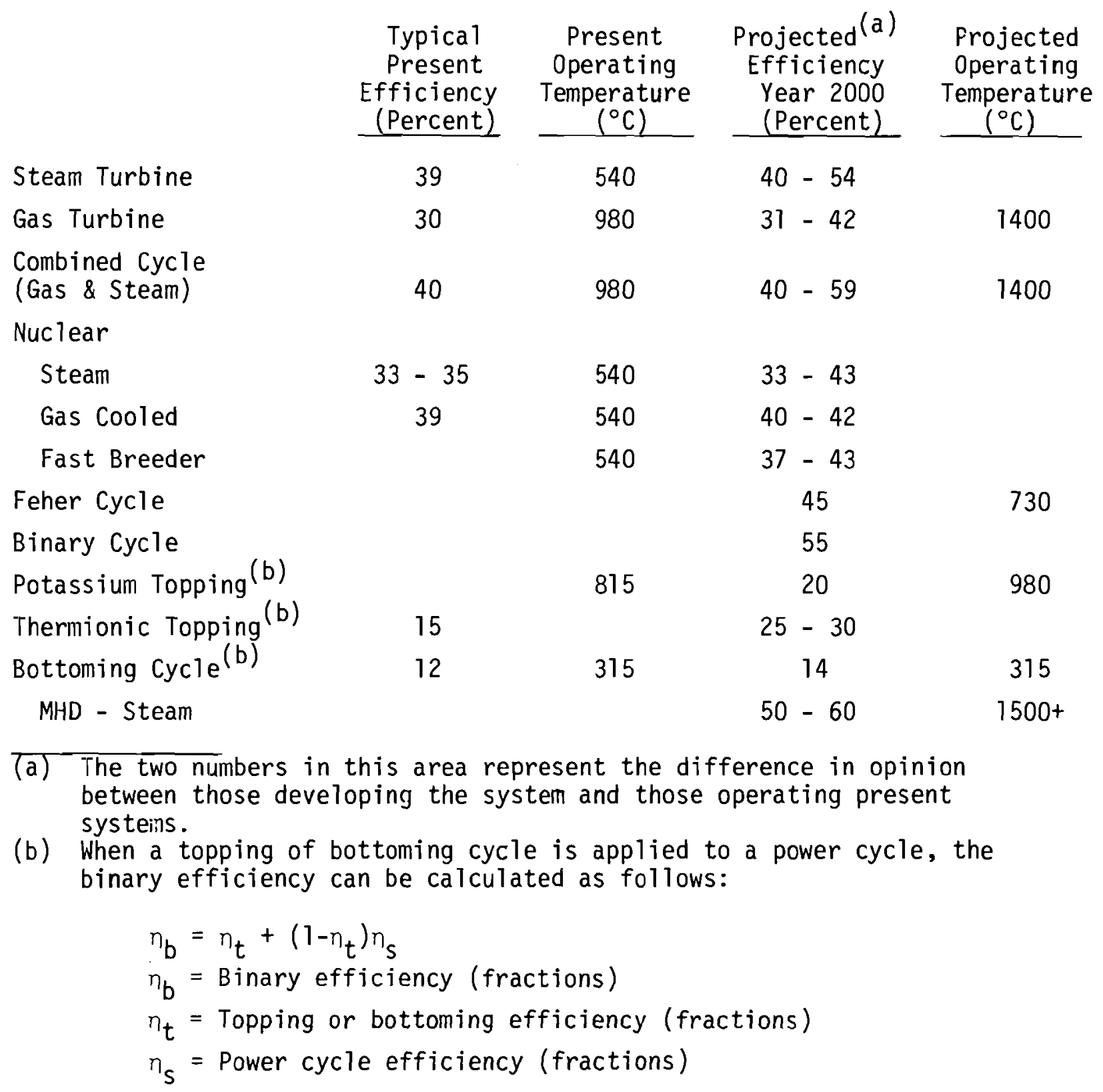


type and design of the heat sink, and the cost of the energy source as well as the system design and materials. The economic and cycle considerations (5) limit steam turbines to an efficiency of 41 percent.

As steam turbine designs have become more refined and as materials have been developed to withstand high temperatures, the attainable efficiency of generating electricity using a thermal source has increased. However, a decrease in the efficiency of energy generation has occurred in the power industry during the past decade. This decrease is due to the more stringent controls set on emmisions and to the increased use of less costly, less efficient energy conversion systems.

Interest in gas turbines increased over the last two decades because of the reduced capital expense for such a system to supplement peak electrical network power demands and because higher temperature applications are possible. Gas turbines can still expect modest increases in system efficiencies.

A system using the principle of magnetohydrodynamics (MHD) for energy conversion is not as temperature limited as steam or gas turbine systems because there are no turbine blades. The MHD surfaces in contact with the hot fluid stream can be easily cooled; therefore higher temperatures can be tolerated. Since major development of MHD did not begin unti1 about 1960, the efficiency of present day systems does not appear to be representative of the MHD potential. The efficiency of a first generation MHD device is projected to reach 50 percent with further development work extending the efficiency to over 60 percent. Some reports optimistically predict efficiencies reaching 75 to 80 percent. $(12,13)$

Another scheme that has been used to increase system efficiency is using combined systems where two or more cycles are operated in tandem. This allows one system to be designed for optimum performance at a high temperature with lower pressures and the other system designed to operate at low temperatures with high pressures. Several working fluids are 
available which allow a wide range of temperature and pressure operation. The combined gas and steam, MHD steam, gas Feher, potassium topping cycles are examples of this approach. However, the operational complexities of combining cycles offer problems to be solved. Heat and mass flows between systems have to be carefully controlled to insure efficient operation. The economics of the design would determine the plant efficiency that is most cost effective.

The environmental pollution of a system must be considered. For a fossil fuel plant, if the emissions of particulate matter or noxious gases are expected to be controlled, energy would be used to process the combustion products and/or further refine the fuel. This could consume as much as 20 percent of the energy output. If the goal is thermal pollution control, then the thermal efficiency of the system must be highly developed. Comparisons are shown in Table 3.

\section{TABLE 3. Waste Heat Emission}

\section{Assumed Efficiency (Percent)}

60

55

50

$40-45$

$35-40$
Possible System

Fossil Fueled - MHD

Binary System

Proposed ORNL-Fusion

Concept Gas - Steam Cycle

Feher Cycle Steam turbines

Gas turbines

Proposed Fusion Reactor Concepts
Waste Heat to

Environment/

Electric Energy

Generated

0.67

0.82

1.0

$1.5-1.22$

$1.9-1.5$ 


\section{CONCLUSIONS}

The currently proposed fusion reactor concepts have estimated therma 1 efficiencies which are generally less than 40 percent or about the same efficiencies as the best current thermal power plant systems. Fossilfueled MHD systems offer potential efficiencies of about 60 percent for the same time period which may also have application to fusion reactors. The lower efficiencies projected for the fusion concepts are due primarily to material property limitations. As long as fusion reactor system designs require the collection of thermal energy at the reactor blanket and the transfer of that energy to a heat exchanger or boiler, the fusion system would appear to have the same efficiency restrictions as present day steam power plants.

Energy conversion technology is well understood. Ample information is available for accurate estimation of the thermal efficiency of a developed energy conversion system. No research appears necessary to assure adequate ability to estimate thermal efficiencies for an environmental statement for either experimental or commercial fusion reactors. 


\section{REFERENCES}

1. B. F. Gore and P. L. Hendrickson, Fuel Procurement for First Generation Fusion Power Plants, BNWL-2012, Battelle, Pacific Northwest Laboratories, Richland, WA, 1976.

2. B. F. Gore, Current Fusion Power Plant Design Concepts, BNWL-2013 Battelle, Pacific Northwest Laboratories, Richland, WA, 1976.

3. R. W. Moir, W. L. Barr, and G. A. Carlson, Direct Conversion of Plasma Energy to Electricity for Mirror Fusion Reactors, California University at Livermore, UCRM-76051, 24 Sep 1974.

4. R. W. Boom, G. L. Kulcinski, C. W. Maynard, and W. F. Vogelsong, "Engineering Feasibility of a Fusion Reactor," Proceedings of the Ammerican Power Conference, Vol. 35, 1973.

5. T. R. Blackwood and W. H. Hedley, Efficiencies in Power Generation, PB-234 160, Mar 1974.

6. Jean F. Louis, "High Temperature Power Generation," Proceedings of the 1970 Intersociety Energy Conversion Engineering Conference, Vo1. 2, 1970.

7. Heat Sink Design and Cost Study for Fossil and Nuclear Power Plants, WASH-1360, USAEC, DeC 1974.

8. W. S. Ku and V. T. Sulzberger, "Year 2000 Generation and Transmission Plan," Proceedings of the American Power Conference, Vol. 35, 1973.

9. J. C. Swidler, "The Fuel Shortage and Conversion Efficiency," Proceedings of the American Power Conference, Vol. 35, 1973.

10. R. Henne and W. Weber, "Experiments with Low - Pressure - CS Diodes with Cermet - Emitters Operating and Emitter - Temperature of About $1250 \mathrm{C}, "$ Proceedings of 9th Intersociety Energy Conversion Conference, 1974.

11. An Efficiency Comparison of Feher Cycle Variants with Other Advanced Cycles, MDC U0038, pp. 1-6, 2-2, and 2-5, McDonald Douglas Corporation, Mar 1974.

12. M. A. Kettani, Direct Energy Conversion, Addison Wesley Publishing Company, Reading, MA, 1970.

13. R. J. Rosa, Evaluation of a Blanket-Coupled Fusion MHD Power Genera-tion System, (Report prepared for Brookhaven National Laboratory by Avco Everett Research Laboratory, Inc.), Jan 1975.

14. A. E. Sheindlin and W. D. Jackson, "MHD Electrical Power Generation, An International Status Report," Ninth World Energy Conference, Detroit, MI, Sep 22-27, 1974. 
15. R. J. Brouns, Environmental Impacts of Nonfusion Power Plants, BNWL-2027, Battelle, Pacific Northwest Laboratories, Richland, WA 1976. 


\section{A. A. Churm ERDA Chicago Patent Group \\ 9800 S. Cass Avenue \\ Argonne, IL 60439}

J. W. Beal

ERDA Div. of Magnetic

Fusion Energy

Washington, DC 20545

S. 0. Dean

ERDA Div. of Magnetic Fusion Energy

Washington, DC 20545

E. E. Kintner

ERDA Div. of Magnetic

Fusion Energy

Washington, DC 20545

J. M. Williams

ERDA Div. of Magnetic Fusion Energy

Washington, DC 20545

J. N. Grace

ERDA Div. of Magnetic

Fusion Energy

Washington, DC 20545

J. Baublitz

ERDA Div. of Magnetic

Fusion Energy

Washington, DC 20545

3 F. E. Coffman

ERDA Div. of Magnetic

Fusion Energy

Washington, DC 20545

J. F. Decker

ERDA Div. of Magnetic

Fusion Energy

Washington, DC 20545

3 K. M. Zwilsky

ERDA Div. of Magnetic Fusion Energy

Washington, DC 20545

Dr. Philip M. Stone

ERDA Applied Plasma Physics

Program

Washington, DC 20545

G. W. Kuswa

ERDA Div. of Laser Fusion

Washington, DC 20545
R. Blaunstein

ERDA Div. of Biomedical

and Environmental Research

Washington, DC 20545

H. M. Busey

ERDA Div. of Military

Application

Washington, DC 20545

M. A. Bell

ERDA Div. of Safety

Standards and Compliance

Washington, DC 20545

27 ERDA Technical Information Center

M. S. Kaminsky

Argonne National Laboratory

9700 S. Cass Avenue

Argonne, IL 60439

V. A. Maroni

Argonne National Laboratory

$9700 \mathrm{~S}$. Cass Avenue

Argonne, IL 60439

P. M. Persiani

Argonne National Laboratory

9700 S. Cass Avenue

Argonne, IL 60439

M. Petrick

Engineering and Technology

Division

Argonne National Laboratory

9700 S. Cass Avenue

Argonne, IL 60439

W. E. Parkins, Manager

Atomics International

Component Engineering and

Technology Division

North American Rockwell

P. 0. Box 309

Canoga Park, CA 91304

D. Gurinsky

Brookhaven National Laboratory

ERDA Brookhaven Area Office

Upton, NY 11973

\section{H. J. Kouts}

Brookhaven National Laboratory ERDA Brookhaven Area Office

Upton, NY 11973

S. Pearlstein

Brookhaven National Laboratory ERDA Brookhaven Area Office Upton, NY 11973
J. R. Powell

Brookhaven National Laboratory ERDA Brookhaven Area office Upton, NY 11973

A. J. Impink, Jr.

Carnegie Mellon University

Pittsburgh, PA 15213

R. A. Gross

Plasma Research Laboratory

236 SW Mudd Bldg.

Columbia University

New York, NY 10027

W. C. Gough

Electric Power Research Inst.

$3412 \mathrm{Hillview} \mathrm{Ave.}$

Palo Alto, CA 94304

G. R. Hopkins

Gulf General Atomic

P.0. Box 1111

San Diego, CA 92112

Zeinab Sabri

Iowa State University

261 Sweeney Hall

Nuclear Engineering Department Ames, IA 50010

R. Borg

Lawrence Livermore Laboratory

P.0. Box 808

Livermore, CA 94550

T. K. Fowler

Lawrence Livermore Laboratory P.0. Box 808

Livermore, CA 94550

R. Moir

Lawrence Livermore Laboratory

P.0. Box 808

Livermore, CA 94550

A. Carl Haussmann

Lawrence Livermore Laboratory

P.0. Box 808

Livermore, CA 94550

J. Hovingh

Lawrence Livermore Laboratory

P.0. Box 808

Livermore, CA 94550

R. F. Post

Lawrence Livermore Laboratory

P.0. Box 808

Livermore, CA 94550

C. J. Taylor

Lawrence Livermore Laboratory P.0. Box 808

Livermore, CA 94550 
$R$. Werner

Lawrence Livermore

Laboratory

P.0. Box 808

Livermore, CA 94550

L. L. Wood

Lawrence Livermore

Laboratory

P.0. Box 808

Livermore, CA 94550

W. Baver

Division Supervisor of Physical Research

Sandia Labs Livermore

Livermore, CA 94550

L. Booth

Los Alamos Scientific Laboratory

CTN Research

P.0. Box 1663

Los Alamos, NM 87544

D. J. Dudziak

Los Alamos Scientific

Laboratory

CTN Research

P.0. Box 1663

Los Alamos, NM 87544

D. B. Henderson

Los Alamos Scientific Laboratory

CTN Research

P.0. Box 1663

Los Alamos, NM 87544

E. L. Kemp

Los Alamos Scientific

Laboratory

CTN Research

P.0. Box 1663

Los Alamos, NM 87544

F. L. Ribe

Los Alamos Scientific

Laboratory

CTN Research

P.0. Box 1663

Los Alamos, NM 87544

L. Stewart

Los Alamos Scientific Laboratory

CTN Research

P.0. Box 1663

Los Alamos, NM 87544

K. Thomassen

Los Alamos Scientific

Laboratory

CTN Research

P.0. Box 1663

Los Alamos, NM 87544
0. K. Harling

Massachusetts Institute of Technology

Cambridge, MA 02139

Bruno Coppi

Department of Physics

Massachusetts Institute of

Technology

Cambridge, MA 02139

L. Lidsky

Dept. of Nuclear Engineering

Massachusetts Institute of

Technology

Cambridge, MA 02139

Norm Rasmussen

Dept. of Nuclear Engineering

Massachusetts Institute of

Technology

Cambridge, MA 02139

David Rose

Massachusetts Institute of

Technology

Cambridge, MA 02139

R. E. Stickney

Mechanical Engineering

Massachusetts Institute of

Technology

Cambridge, MA 02139

J. J. Reinmann

NASA - Lewis Research Center

2100 Bookpark Rd.

Cleveland, $\mathrm{OH} \quad 44135$

Vincent Arp

National Bureau of Standards

Cryogenics Division

Boulder, C0 80302

J. F. Clarke

Oak Ridge Nationa]

Laboratory

P.0. Box $Y$

Oak Ridge, TN 37830

A. P. Fraas

Oak Ridge National

Laboratory

P.0. Box Y

Oak Ridge, TN 37830

J. Rand MeNally, Jr.

Oak Ridge National

Laboratory

P. 0. Box Y

Oak Ridge, TN 37830

D. Steiner

Oak Ridge National

Laboratory

P. 0. Box Y

Oak Ridge, TN 37830
OFFSITE

3. $S \cot t$

Oak Ridge National Laboratory

P. 0. Box X

Oak Ridge, TN 37830

J. Banford

Physics International

2700 Merced St.

San Leandro, CA 94577

R. A. Huse

Public Service Electric

and Gas Co.

80 Park Place

Newark, NJ 07101

M. Gottlieb

Princeton University, PPPL

P. 0 . Box 451

Princeton, NJ 08540

R. G. Mills

Princeton University

P.0. Box 451

Princeton, NJ 08540

E. C. Tanner

Princeton University

P. 0. Box 451

Princeton, NJ 08540

H. Perkins

Dept. of Chemistry

Princeton University

Princeton, NJ 06540

R. E. Gold

303 Sayre Hall

Forresta 1 Campus

P.0. Box 451

Princeton, NJ 06540

M. Kristiansen

Texas Tech. University

Lubbock, TX 79409

A. F. Haught

United Aircraft Research Lab.

United Aircraft Corporation

East Hartford, CT 06108

L. Levine

U.S. Naval Research Laboratory

Washington, DC 20390

C. Z. Serpan, Jr.

U.S. Naval Research Laboratory

Washington, DC 20390

Francis Chen

University of California

Electronics Research

Laboratory

College of Engineering

Berkeley, CA 94720 
A. J. Lichtenberg University of California Electronics Research Laboratory

College of Engineering Berkeley, CA 94720

Dave Okrent

U.C.L.A.

Los Angeles, CA 90024

C. D. Hendricks University of Illinois Nuclear Engineering Laboratory Urbana, IL 61801

G. H. Miley University of Illinois Nuclear Engineering Laboratory Urbana, IL 61801

Terry Kammash University of Michigan Nuclear Engineering Department

Ann Arbor, MI 48105

Dean Abrahamson University of Minnesota School of Public Affairs

Social Science

Building/309

Minneapolis, MN 55455

W. G. Davey

University of Texas

Department of Physics

Austin, TX 78712

E. Linn Draper, Jr. University of Texas Department of Physics Austin, TX 78712

W. E. Drummond University of Texas Department of Physics Austin, TX 78712

Abraham Hertzberg University of Washington Aerospace Research

Laboratory

316 Guggenheim

Seattle, WA 98105

A. L. Babb

University of Washington

Nuclear Engineering

Department

Seattle, WA 98105
R. Conn

University of Wisconsin

Nuclear Engineering

Department

Madison, WI 53706

G. L. Kulcinski

University of Wisconsin

Nuclear Engineering

Department

Madison, WI 53706

C. W. Maynard University of Wisconsin Nuclear Engineering

Department

Madison, WI 53706

D. Lichtman

Department of Physics

University of Wisconsin

Milwaukee, WE 53201

E. E. Donaldson

Washington State University

Deparment of Physics

Pulliman, WA 99163

D. D. Mahium

Division of Biomedical

and Environmental Research

Washington, DC 20545

J. V. Vanston

Engineering Science

Building

University of Texas

Austin, TX 78712

Leslie S. Ramsey

450 North 5 th Street

Indiana, PA 15701 
EROA Richland Operations Office

W. A. Burns

Atlantic Richfield Hanford Company

J. D. Kaser

Hanford Engineering

Development Labs

D. G. Doran

H. H. Yoshikawa

Battelle-Northwest

D. T. Aase

G. S. Allison

T. W. Ambrose

D. G. Atteridge

D. A. Baker

J. L. Bates

M. A. Bayne

E. R. Bradley

J. L. Brimha 11

R. L. Brodzinski

R. J. Brouns

L. R. Bunnell

L. L. Burger

S. H. Bush

N. E. Carter

T. D. Chikalla

R. G. Clark

T. L. Criswell

S. D. Dahlgren

M. T. Dana

D. E. Deonigi

R. L. Dillon

D. A. Dingee

P. J. Dionne

B. H. Duane

J. W. Finnigan

J. C. Fox

J. J. Fuquay

J. E. Garnier

R. D. Gastil

B. F. Gore

J. N. Hartley

A. J. Haverfield

U. P. Jenquin

A. B. Johnson, Jr.

R. H. Jones

T. J. Kabele

W. S. Kelly

H. E. Kissinger

D. A. Kottwitz

N. Laegried

B. R. Leonard, Jr

D. L. Lessor

H. B. Li emohn

R. C. Liikala

10 M. A. Mckinnon

R. F. Maness

R. P. Marshall
Battelle-Northwest - Continued

E. S. Murphy

R. D. Welson

D. F. Newman

R. E. Nightingale

D. E. Olesen

L. T. Pedersen

R. T. Perry

D. R. Pratt

L. A. Rancitelli

J. F. Remark

U. S. Renné

R. E. Rhoads

W. D. Richmond

W. F. Sandusky

L. C. Schmid

N. M. Sherer

E. P. Simonen

R. I. Smith

J. K. Soldat

C. W. Stewart

K. B. Stewart

R. W. Stewart

J. A. Strand

D. L. Styris

A. M. Sutey

V. L. Teofilo

G. L. Tingey

M. T. Thomas

R. C. Thompson

L. H. Toburen

T. J. Trapp

R. Wang

R. E. Westerman

L. D. Williams

10 J. R. Young

M. G. Zimmerman

1 Technical Publications (BH)

5 Technical Information 